\title{
The Role of Motivation in Self-regulated Learning and Language Learning Strategy: In the Case of Chinese EFL Learners
}

\author{
Maryam Banisaeid (Corresponding author) \\ School of International Studies, Zhejiang University \\ Room 2002A, Block4, Gangwan Jiayuan, Zijingang Campus, Zhejiang University, Hangzhou, PR China, 310030 \\ E-mail: banymary@yahoo.com \\ Jianbin Huang \\ School of International Studies, Zhejiang University \\ Zijingang Campus, Zhejiang University, Hangzhou, PR China, 310058 \\ E-mail:jianbinhuang32@126.com
}

Received: 08-01- 2015

Published: 01-09- 2015
Accepted: 10-03- 2015

doi:10.7575/aiac.ijalel.v.4n.5p.36
Advance Access Published: April 2015

URL: http://dx.doi.org/10.7575/aiac.ijalel.v.4n.5p.36

\begin{abstract}
Although self-regulation, derived from educational psychology, is a new topic in the second language learning field, language learning strategy was the main focus of many studies in the last two decades. Also, among the L2 individual differences, motivation plays an important role in achieving the educational goals. In this research, motivation is investigated from self-determination theory by which five types of motivation are presented. No study was found to investigate the role of motivation in both self-regulation and language learning strategy. For such a purpose, 49 Chinese EFL learners respond to SILL, MSLQ and LLOS_IEA respectively proposed by Oxford (1990), Pintrich et al (1991) and Noel et al (2000). The results running Pearson correlation showed that there is a significant relationship between motivation, self-regulation and language learning strategies. It is also revealed that Chinese EFL learners use memory, social and affective strategy more than the other ones. The most common motivational orientation is identified regulation. Among self-regulated learning strategies, effort regulation is highly used by them. At the end some implication is considered.
\end{abstract}

Keywords: motivation, language learning strategy, self-regulation, self-determination theory

\section{Introduction}

Training autonomous learners who self-regulate their own learning is one of the most recent trends in the last two decades. Today, the approach of teacher-center is replaced by learner-center, so the role and responsibly of the individuals are more important and change from passive to active. The impetus for teaching learners" how to learn" came from the work of Rubin and Stern in the mid nineteen century on the work of poor and good language learners. This was followed by many scholars who finally tried to shape a classification of strategies (Brown, 2007). Language learning strategies were the focus of many studies during the last two decades (Banisaeid 2013a, 2013b, Banisaeid \& Huang, 2014; Cohen, 1998; Dörnyei, 2005; Ellis, 1994; Goh, 2002; Griffiths, 2003, 2007; Griffiths \& Oxford, 2014; O'Malley \& Chamot, 1990; Oxford, 1990, 2003; Oxford, Rubin, Chamot, Schramm, Lavine, Gunning \& Nel, 2014; Oxford, Griffiths, Longhini, Cohen, Macaro \& Harris , 2014; Ridley, 1997; Stern, 1992). The emergence of language learning strategies led to strategy-instruction or strategy training by which learners were able to use different types of strategies for regulating their own learning. Some scholars try to replace the strategic framework with the notion of selfregulation which is originally derived from educational psychology (Banisaeid \& Huang, 2014; Dörnyei 2005; Rose, 2012; Tseng, Dörnyei \& Schmitt, 2006). On the other hand, the ultimate goal of strategy-instruction is to train autonomous and self-regulated learners.

Zimmerman (1989) defines self-regulation as the degree that learners are "metacognitively, motivationally and behaviorally active participants in their own learning process" (p. 329). The broader notion "self-regulation" was used as a replacement to language learning strategies in some studies because of definitional fussiness and difficulty in measurement. (Banisaeid \& Huang, 2014; Dörnyei, 2005; Tseng et al., 2006; Rose, 2012).

Individual differences as language aptitude, motivation, learning style, self-esteem, anxiety, learner's belief and creativity affect second language acquisition (Dörnyei, 2005). Oxford (1990) states "more highly motivated learners use a significantly greater range of appropriate strategies than do less motivated learners" (p.13). 


\section{Review of the Literature}

\subsection{Motivation}

Among the L2 individual differences, motivation plays an important role in achieving the educational goals. Dörnyei (2012) declares that there is considerable amount of research on L2 motivation in the last three decades. Dörnyei (2005) provides a concise overview of the L2 motivation research and divides the history into three phases:

(a) The social psychological period (1959-1990)—characterized by the work of Gardner and his students and associates in Canada.

(b) The cognitive-situated period (during the 1990s) — characterized by work drawing on cognitive theories in educational psychology.

(c) The process-oriented period (the past five years) - characterized by an interest in motivational change, initiated by the work of Dörnyei, Ushioda, and their colleagues in Europe (p. 66-67).

In the first phase, L2 motivation research came from social psychologists working in Canada, from Wallace Lambert and Robert Gardner (Dörnyei, 2005). Integrativeness and instrumentality are the results of Gardner's motivational works in this period (Dörnyei, 2012).

- Integrative motivation: "positive disposition toward the L2 group and the desire to interact with and even become similar to valued members of that community".

- Instrumental motivation:"it is related to potential pragmatic gains of L2 proficiency such as getting a job or higher salary" (Dörnyei, 2012, p. 17).

In the field of language learning, although there are some works that deal with these two types of motivation (Moriam, 2008; Rahimi et al., 2012; Rahman, 2005), few study was found to use cognitive theories introduced in the second phase of motivation history.

In the second phase, self-determination theory was introduced by Deci \& Ryan (Dörnyei, 2012).

"According to self-determination theory, there are two general types of motivation, one based on intrinsic interest in the activity per se and the other based on rewards extrinsic to the activity itself. These types of motivation are not categorically different, however, but rather lie along a continuum of selfdetermination". (Noel, Pelletier \& Vallerand, 2000, p. 60)(Figure 1).

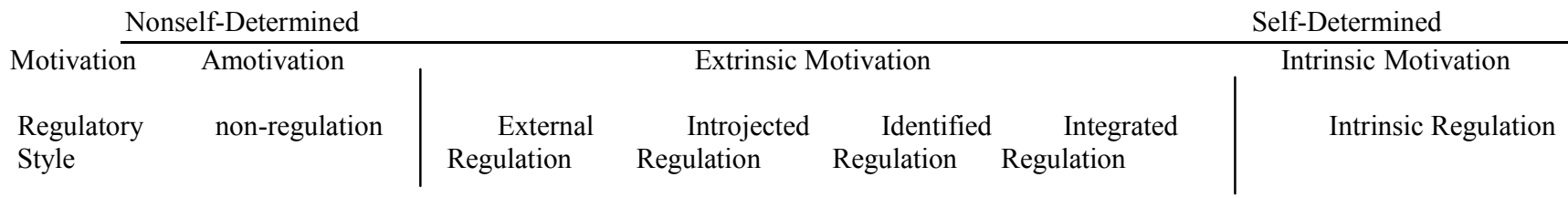

Figure1. The Self-Determination Continuum Showing Types of Motivation with Their Regulatory Styles (Ryan \& Deci, 2000, p 72).

Noels et al. (2000) present five basis of language learning motivation that lie along the continuum of intrinsic and extrinsic motivation (also cited in Dörnyei, 2005, p. 78)

1. Amotivation: A lack of motivation caused by the realization that 'there is no point...'or 'it's beyond me...' E.g., [Why are you learning the L2?] Honestly, I don't know, I truly have the impression of wasting my time in studying a second language.

2. External Regulation: The least self-determined form of extrinsic motivation, coming entirely from external sources such as rewards or threats (e.g., teacher's praise or parental confrontation). E.g., because I have the impression that it is expected of me.

3. Introjected Regulation: Externally imposed rules that the student accepts as norms he/she should follow so as not to feel guilty (e.g., rules against playing truant). E.g., because I would feel guilty if I didn't know a second language.

4. Identified Regulation: The person engages in an activity because he/she highly values and identifies with the behavior, and sees its usefulness (e.g., learning a language which is necessary to pursue one's hobbies or interests). E.g., because I think it is good for my personal development.

5. Intrinsic Motivation

- Knowledge: Doing the activity for the feelings associated with exploring new ideas and acquiring knowledge. E.g., for the satisfied feeling I get in finding out new things.

- Accomplishment: Sensations related to attempting to master a task or achieve a goal. E.g., for the satisfaction I feel when I am in the process of accomplishing difficult exercises in the second language 
- Stimulation: Sensations stimulated by performing the task, such as aesthetic appreciation or fun and excitement. E.g., for the 'high' feeling that I experience while speaking in the second language (Dörnyei,, 2005, p. 78)

\subsection{Self-regulation}

In the field of SLA, some scholars newly attempt to borrow the term "self-regulation" from educational psychology (Banisaeid \& Huang, 2014; Dörnyei, 2005; Rose, 2012; Tseng et al., 2006). Self-regulation refers to "self-generated thoughts, feelings, and actions that are planned and cyclically adapted to the attainment of personal goals (Zimmerman, 2000, p.14). According to Schunk and Ertmer (2000), self-regulation is cyclical in nature since personal, behavioral and environmental factors change during learning. From a social cognitive perspective, self-regulation is an interaction between personal, behavioral and environmental triadic processes (Bandura, 1988). From a social cognitive perspective, self-regulatory processes and accompanying beliefs fall into three cyclical phases: forethought, performance or volitional control, and self-reflection processes (Zimmerman, 2000, p. 16) (table1).

Table 1. Phase Structure and Sub processes of Self-Regulation (Zimmerman, 2000, p. 16)

Cyclical self-regulatory phases

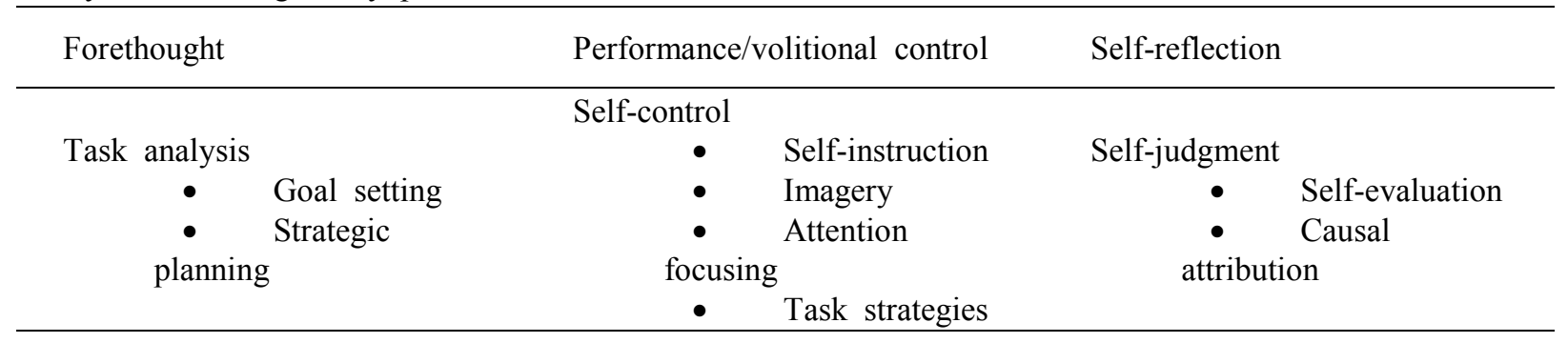

Self-motivation beliefs

- $\quad$ Self-efficacy
- $\quad$ Outcome
expectations
- Intrinsic
interest/value
- $\quad$ Goal orientation

Self-observation

- $\quad$ Self-recording

- Self-

experimentation
Self-reaction
- Self-
satisfaction/affect
- $\quad$ Adaptive-
defensive

Pintrich (2000) classifies four basic assumptions which are common among different models of self-regulated learning.

1. Active, constructive assumption: learners are active participant in learning process.

2. The potential for control assumption: learners can potentially monitor, control, and regulate certain aspects of their own cognition, motivation, and behavior as well as some features of their environments.

3. Goal, criterion, or standard assumption; in all models, there is criteria also called goal or standard by which learners assess learning process.

4. Self-regulatory activities are mediators between personal and contextual characteristics and actual achievement or performance.

Self-regulation includes some strategies that shape it. Pintrich and his colleagues (1991) propose motivated strategies for learning questionnaire which includes two main parts: motivational orientation and learning strategies (table 2).

Table 2. Self-regulated learning

Motivational orientation

\begin{tabular}{|c|c|c|c|c|c|}
\hline $\begin{array}{l}\text { Value } \\
\text { component }\end{array}$ & $\begin{array}{l}\text { Expectancy } \\
\text { component }\end{array}$ & $\begin{array}{l}\text { Affective } \\
\text { component }\end{array}$ & $\begin{array}{l}\text { Cognitive } \\
\text { metacognitive strategies }\end{array}$ & and & Resource management \\
\hline $\begin{array}{l}\text { Intrinsic goal } \\
\text { orientation } \\
\text { Extrinsic } \\
\text { goal orientation } \\
\text { Task value }\end{array}$ & $\begin{array}{l}\text { Control of } \\
\text { learning beliefs } \\
\text { Self-efficacy } \\
\text { for learning and } \\
\text { performance }\end{array}$ & Test anxiety & $\begin{array}{l}\text { Rehearsal } \\
\text { Elaboration } \\
\text { Organization } \\
\text { Critical thinking } \\
\text { Metacognitive } \\
\text { regulation }\end{array}$ & self- & $\begin{array}{l}\text { Time and } \\
\text { environment } \\
\text { Effort regulation } \\
\text { Peer learning } \\
\text { Help seeking }\end{array}$ \\
\hline
\end{tabular}




\subsection{Language learning strategies}

Brown (2007) asserts that the first effort leading to some very careful defining of specific learning strategies came from works on poor and good learners and individual variations by Rubin and Stern in the mid 1970s. This beginning point was then followed by many scholars who tried to shaped different classifications of language learning strategies (Dörnyei, 1995; O’Malley \& Chamot, 1989; Oxford, 1990). By the emergence of language learning strategies, many scholars recommended teaching learners how to learn and stated that facilitating autonomy through strategy instruction should be the most important goal of language teaching (Brown, 2007). Ellis (1994) emphasizes on the mediating role of strategy between learners and situational factors and learning outcomes. He defines learning strategy as "the particular approaches or techniques that learners employ to try to learn as L2" (1997, P. 76-77). "The special thoughts or behaviors that individuals use to help them comprehend, learn, or retain new information “(O'Malley \& Chamot, 1990). By different definitions, it can be deduced that any technique, approach, thought or behavior which can be conscious or unconscious that leads to learning is defined as a strategy. Accordingly, different classification of language learning strategies came into existence. Oxford (1990) classified the general learning strategies into two main categories: direct (cognitive, memory and compensation) and indirect (metacognitive, affective, social). Oxford's classification consists of sixty two strategies, 35 in direct and 27 in indirect strategies (Ellis, 1994). Ellis (1994) states "perhaps the most comprehensive classification of learning strategies to date is that provided by Oxford (p. 539; also in Brown, 2 001, p. 217) (Table 3)

Table 3. Language learning strategies (Oxford, 1990)

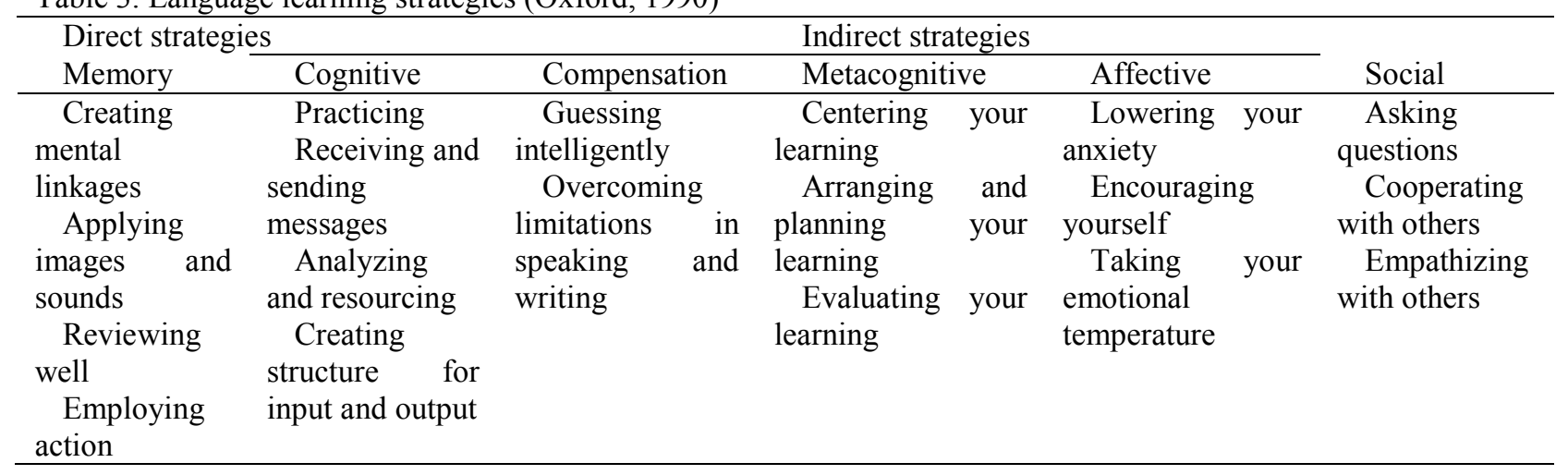

\subsection{Current perspective}

The ultimate goal of strategy training is autonomy and self-regulation. Benson (2007) mentions that the history of autonomy in language education is well-documented. Spratt et al. (2002) declare that motivation is a key factor which influences autonomy (also in Gordon, 2013). Since the other name of self-regulation is autonomy (Bandura, 1991) and the goal of strategy instruction is to train self-regulated and autonomous learners, motivation is regarded as a main factor. So the purpose of the study is to investigate the effect of motivation on autonomy.

\section{Research questions}

The purpose of the study is answering the following questions:

- Is there any significant relationship between motivation and EFL learners' self-regulation and their language learning strategy uses?

- What is the most frequent language learning strategy used by Chinese EFL learners?

- What motivational orientation is common among Chinese EFL learners?

- What is the most frequent self-regulated learning strategy used by Chinese EFL learners?

\section{Methodology}

\subsection{Subject}

49 (42 females and 7males) Chinese EFL learners at Zhejiang University took part in the study. Their mean age was 19. They were all freshman at different majors in humanities. They study English as a second language. Their mother tongue was Chinese.

\subsection{Instruments}

\subsubsection{Strategy Inventory for Language Learning (SILL)}

At first, there are six questions concerning the characteristics of the learners: their names, age, e-mail, sex, years of study and major. The questionnaire proposed by Oxford (1990) includes 50 item in six parts by which learners respond among three choices of always, sometimes and never. The parts are respectively memory, cognitive, compensatory, metacognitive, affective and social strategies. The reliability of this three point Likert scale is .87 . 


\subsubsection{Motivated Strategies for Learning Questionnaire (MSLQ)}

The questionnaire includes 50 statements that are written without headline. These 50 items on the instrument that are scored using a seven point Likert scale were directed to reveal how much subjects regulate their own learning process through subparts of rehearsal, elaboration, organization, critical thinking, metacognitive self-regulation, time study and environmental management, effort regulation, peer learning and help seeking. Seven choices are from "not all very true" to "very true of me". The reliability of the questionnaire is .85 via Cronbach alpha.

\subsubsection{Language Learning Orientation Scale (LLOS_IEA)}

The scale proposed by Noels et al (2000) includes five parts, respectively: Amotivation, External regulation, Introjected regulation, Identified regulation and Intrinsic motivation. The questionnaire consists of 21 items by which learners respond from "not at all true of me" to "true of me" (seven likert point scale)

\subsection{Procedure}

The student filled out the questionnaires without time limit. At first, they were asked to complete six questions concerning their characteristics: their names, age, e-mail, sex, years of study and major. Then they answered to the questionnaires.

\section{Result}

The result related to the relationship between motivation, self-regulation and language learning strategy indicates that there are significant relationships between these three variables (Table 4)

\section{Table 4. Correlations}

\begin{tabular}{|c|c|c|c|c|}
\hline & & $\begin{array}{l}\text { Language learning } \\
\text { strategies }\end{array}$ & Self-regulation & Motivation \\
\hline \multirow{3}{*}{$\begin{array}{l}\text { Language learning } \\
\text { strategies }\end{array}$} & Pearson Correlation & 1 & $-.603^{* *}$ & $-.465^{* *}$ \\
\hline & Sig. (2-tailed) & & .000 & .001 \\
\hline & $\mathrm{N}$ & 49 & 49 & 46 \\
\hline \multirow[t]{2}{*}{ Self-regulation } & Pearson Correlation & $-.603^{* *}$ & 1 & $.427^{* *}$ \\
\hline & Sig. (2-tailed) & .000 & & .003 \\
\hline \multirow{4}{*}{ Motivation } & $\mathrm{N}$ & 49 & 49 & 46 \\
\hline & Pearson Correlation & $-.465^{* *}$ & $.427^{* *}$ & 1 \\
\hline & Sig. (2-tailed) & .001 & .003 & \\
\hline & $\mathrm{N}$ & 46 & 46 & 46 \\
\hline
\end{tabular}

**. Correlation is significant at the 0.01 level (2-tailed).

The overall self-regulated learning strategies shows that the most frequent strategies used by EFL learners is effort regulation followed by time/study environmental management, organization, peer Learning and help Seeking. Table 5 also indicates that EFL learners in this study use all categories and strategies of self-regulation.

\begin{tabular}{lcc} 
Table 5. Mean value of overall self-regulated strategies in seven Likert point scale \\
\hline Scale & Mean & SD \\
1. Rehearsal & 4.04 & 1.82 \\
2. Elaboration & 3.96 & 1.72 \\
3. Organization & 4.46 & 1.72 \\
4. Critical Thinking & 3.96 & 1.70 \\
5. Metacognitive Self-Regulation & 3.79 & 1.72 \\
6. Time/Study Environmental Management & 4.75 & 1.61 \\
7. Effort Regulation & 5.37 & 1.42 \\
8. Peer Learning & 4.33 & 1.84 \\
9. Help Seeking & 4.25 & 1.77
\end{tabular}

Descriptive statistical analyses were used to investigate which language learning strategies are used by the subjects. The Strategy Inventory of Language Learning indicates that Chinese EFL learners use all the six types of categories. The 
overall strategy use shows that respectively memory, affective and social strategies are the most frequent strategies used by subjects (table 6).

Table 6. Mean value of overall strategy use in three Likert point scale

\begin{tabular}{ccc} 
Strategy category & Mean & SD \\
\hline A. Memory & 1.98 & 0.60 \\
B. Cognitive & 1.81 & 0.37 \\
C. Compensation & 1.73 & 0.08 \\
D. Metacognitive & 1.69 & 0.08 \\
E. Affective & 1.96 & 0.09 \\
F. Social & 1.95 & 0.09 \\
\hline
\end{tabular}

The overall types of motivation shows that the most frequent motivation type used by EFL learners is identified regulation followed by intrinsic motivation (table 7)

Table 7. Mean value of overall learners' motivation on seven Likert point scale

\begin{tabular}{|c|c|c|c|}
\hline Types of motivation & & Mean & Standard deviation \\
\hline Amotivation & & 2.44 & 1.84 \\
\hline External regulation & & 4.88 & 1.71 \\
\hline Introjected regulation & & 2.88 & 1.81 \\
\hline Identified regulation & & 5.31 & 1.66 \\
\hline \multirow{3}{*}{ Intrinsic motivation } & Knowledge & 4.9 & 1.83 \\
\hline & Accomplishment & 4.74 & 1.76 \\
\hline & Stimulation & 4.50 & 1.86 \\
\hline
\end{tabular}

\section{Discussion and conclusion}

The finding of the study showed that there was a significant relationship between language learning strategy use, selfregulation and motivation. The correlation analysis of the study showed the relationship between components of motivation and subcategories of language learning strategies. The researcher found a positive and significant relationship between Amotivation and metacognitive and social strategies. This shows that those EFL learners with no motivation use more metacognitive and social strategies. Planning, monitoring, organizing and evaluating learning as well as having interaction for learning English are the strategies that demotivated learners used. The correlation matrix revealed that there is positive and significant correlation between affective strategy and external, introjected identified and intrinsic motivation (stimulation). It can be deduced that more motivated learners not only used more language learning strategies but also were more self-regulated and successful.

The results of the study showed that the most frequent strategies used by Chinese EFL learners were respectively memory, affective and social strategies. It was also shown that the least frequent ones were metacognitive and compensation strategies. These finding were inconsistence with some of the studies on Chinese EFL learners (Leuy \& Hui, 2011; Nisbet, Tindall \& Arroyo, 2005; Yang, 2007). It was shown that Chinese EFL learners used strategies that dealt with grouping, imagery and some strategies to regulate emotion, motivation and attitudes. They also used strategies which helped to learn a language through interaction. Although many studies on Chinese EFL learners' use of language learning strategies showed that the most frequent strategies used by them is compensation ones (Li, 2005; Liu, 2012; Rao, 2006; Wang, 2012; Zhou, 2007), this study revealed that the least frequent strategy used by Chinese EFL learners is compensation strategy.

The result of the study showed that among motivational orientation, statement asking about the identified and external regulation got the highest degree of learners' choice. According to Noel et al (2000), there are three levels of intrinsic motivation: external regulation, introjedted regulation and identified regulation. It can be deduced that Chinese EFL learners would do activities because of its importance for achieving a valuable goal first of all and then what motivated them were achieving some instrumental ends. In general, it can be concluded that Chinese EFL learners, mostly learnt English because of some extrinsic value. 
The finding of study showed that Chinese EFL learners used time/study environment and effort regulation more than the other self-regulated learning strategies. It showed EFL learners had the ability to control their effort and attention in to the face of distraction. This signified goal commitment. They also had the ability to plan and manage their study time and setting where learning takes place.

\section{Implications of the study}

Some suggestions for self-regulation in teaching different language skills:

1. Make learners motivated in their own learning. Motivated learners are more self-regulated (Ammar, 2009).

2. The role of the feedback is noticeable, since learners are environmentally active participants in their learning in self-regulation. Give more time and pay more attention to the negative, positive or neutral feedback you are giving.

3. Investigate the learners' belief in how well their attitude is toward language skill learning. Try to appreciate the positive expectations and change the negative ones.

4. Train them metacognitively, how to plan, evaluate and monitor their learning process.

5. Help them organize and transform the materials.

6. Make learners aware of the goals. Not only the goals but also their state of awareness and their interest in being aware and their mental presence when learning happens are important.

7. Want them to improve their out of class activities, such as seeking peers, adults or teacher assistance, to review their previous notes, tasks or tests.

\section{References}

Ammar, A. (2009). The effects of self-regulated reading strategy development on the prospective EFL teachers' critical reading skills and reading motivation. Retrieved April 2012 from http://repository.ksu.edu.sa/jspui/handle/123456789/4671

Bandura, A. (1988). Self-regulation of motivation and action through goal systems. In V. Hamilton, G. Bower \& N. Frijda (Eds.), Cognitive Perspectives on Emotion and Motivation, 37 61. Dordrecht, Netherlands: Kluwer Academic.

Bandura, A. (1991). Social cognitive theory of self-regulation. Organizational Behavior and Human Decision Processes, 50, 248-287

Bansaeid, M. (2013a). The Relationship between Self-regulated Learning Strategies and Strategy-based Vocabulary Acquisition of Iranian EFL Learners. The Iranian EFL Journal, 81(3)

Banisaeid, M. (2013b). Comparative Effect of Memory and Cognitive Strategies Training on EFL Intermediate Learners' Vocabulary Learning. English Language Teaching, 6(8).

Banisaeid, M. \& Huang, J. (2014). Self-regulation from Educational Psychology to L2 Pedagogy: an Alternative to Language Learning Strategies. International journal of applied linguistics and English literature, 3(1)

Benson, P. (2007). Autonomy in language teaching and learning. Language Teaching, 40, 21-40.

Brown, H, D. (2007). Principles of language learning and teaching. Pearson education.

Cohen, A. (1998). Strategies in learning and using a second language. London: Longman.

Communities, H., Wang, C., Quach, L. H., \& Rolston, J. (2009). Understanding English language learners' selfregulated learning strategies. New Perspectives on Asian American Parents, Students, and Teacher Recruitment, 73.

Dörnyei , Z. (2005). The psychology of the language learner: Individual differences in second language acquisition. Mahwah, N.J.: L. Erlbaum.

Dörnyei, Z. (2012). Motivation in language learning. Shanghai: Shanghai Foreign Language Education Press.

Ellis, R. (1994). The Study of Second Language Acquisition. Oxford: Oxford University Press.

Goh, C. C. M. (2002). Exploring listening comprehension tactics and their interaction patterns. System, 30(2), 185-206

Gordon, J. (2013). Identity, motivation and autonomy in language learning. Murray Garold, Gao Xuesong, \& Lamb Terry (Eds.). Bristol, UK: Multilingual Matters, 2011. Pp. x+266. Studies in Second Language Acquisition, 35(01), 190-191.

Griffiths, Carol (2003). Patterns of language learning strategy use. System, 31, 367-383

Griffiths, C. (2007). Language learning strategies: Students' and teachers' perceptions. ELT Journal, 61, 91-99.

Griffiths, C., \& Oxford, R. L. (2014). The twenty-first century landscape of language learning strategies: Introduction to this special issue. System, 43, 1-10.

Leung, Y., \& Hui, A. (2011).Language Learning Strategy of Hong Kong Putonghua Learners. Educational Research Journal, 26(1).

Liu, HT (2009). The Scale development and causal-effect studies of self-regulation in English language learning. Unpublished Master's Thesis, National Taiwan the Normal University, Taipei, Taiwan. 
Liu, Min. "Gender and Language Learning Strategy Use-In the Case of Chinese High School Students."Studies in Literature and Language. Canadian Academy of Oriental \& Occidental Culture. 2012. HighBeam Research. 27 Sep. 2013 retrieved from http://www.highbeam.com/doc/1G1-318493753.html

Moriam, Q. (2008). A Study on Motivation and Strategy Use of Bangladeshi University Students to Learn Spoken English. Hiroshima: University of Hiroshima

Noels, K. A., Pelletier, L. G., Clément, R., \& Vallerand, R. J. (2000). Why are you learning a second language? motivational orientations and self-determination theory. Language Learning, 50, 57-85.

Nisbet, D., Tindall, E. R., \& Arroyo, A. A. (2005). Language learning strategies and English proficiencyof Chinese universitystudents. Foreign Language Annuals, 38(1), 100-107.

O'Malley JM, Chamot AU, (1989). Listening comprehension strategies in second language acquisition. Applied Linguistics, 10(4), 418-437.

O'Malley, J. M., \& Chamot, A. U. (1990). Learning strategies in second language acquisition. Cambridge, England: Cambridge University Press.

Oxford, R. L. (2003). Language learning styles and strategies: An overview. GALA. Retrieved October 6, 2009, from: http://www.education.umd.edu/EDCI/SecondLangEd/ TESOL/People/Faculty/Dr\%20Oxford/StylesStrategies.doc

Oxford, R. L., Rubin, J., Chamot, A. U., Schramm, K., Lavine, R., Gunning, P., \& Nel, C. (2014). The learning strategy prism: Perspectives of learning strategy experts. System, 43, 30-49.

Oxford, R. L., Griffiths, C., Longhini, A., Cohen, A. D., Macaro, E., \& Harris, V. (2014). Experts' personal metaphors and similes about language learning strategies. System, 43, 1129.

Oxford, R. L. (1990). Language learning strategies: What every teacher should know. New York: Newbury House

Pintrich, P.R. (2000). The role of goal orientation in self-regulated learning. In M. Boekaerts, P.R. Pintrich \& M. zeidner (eds), Handbook of Self-regulation. San Diego, CA: Academic Press.

Pintrich, P. R., Smith, D. A. F., Garcia, T., \& McKeachie, W. J. (1991). A manual for the use of the Motivated Strategies for Learning Questionnaire (MSLQ). Ann Arbor: University of Michigan, National Center for Research to Improve Postsecondary Teaching and Learning.

Rahimi, M., Roohani, A. \& Akbari, R. (2012) On the relationship between language learning strategy use and motivation. Language,Linguistics and Literature,The Southeast Asian Journal of English Language Studies., 18 (4), 131-144.

Rahman, S. (2005). Orientations and motivation in English language learning: A study of Bangladeshi students at undergraduate level. Asian EFL Journal, 7, 29-55

Rao, Z (2006). Understanding Chinese Students' Use of Language Learning Strategies from Cultural and Educational Perspectives. Journal of multilingual and multicultural development 27, 491-508.

Ridley, J. (1997). The role of the first language in foreign language learning. Philadelphia: Multilingual Matters. Purpura, J. (1999). Learner strategy use and performance on language tests. A structural equation modelling approach. Cambridge, England: Cambridge University Press.

Rose, H. (2012). Reconceptualizing Strategic Learning in the Face of Self-Regulation: Throwing Language Learning Strategies out with the Bathwater. Journal of Applied Linguistics, 33(1), 92-98.

Ryan, R. M., \& Deci, E. L. (2000). Self-determination theory and the facilitation of intrinsic motivation, social development, and well-being. American psychologist, 55(1), 68.

Schunk, D. H., \& Ertmer, P. A. (2000). Self-regulation and academic learning: Self-efficacy enhancing interventions.

Spratt, M., Humphreys, G., \& Chan, V. (2002). Autonomy and motivation: Which comes first? Language Teaching Research, 6, 245-266

Tseng, W. T., Dörnyei, Z. \& Schmitt, N. (2006). A new approach to assessing strategic learning: the case of self-regulation in vocabulary acquisition. Applied Linguistics,78-102.

Wang, C. (2012). Pre-service teachers' perceptions of learning a foreign language online: Preparing teachers to work with linguistic, cultural, and technological diversity. International Journal of Computer-Assisted Language Learning and Teaching, 2(1), 30-45.

Zimmerman, B. J. (1989). A social cognitive view of self-regulated academic learning. Journal of Educational Psychology, 81, 329-339.

Zimmerman, B. (2000). Attaining self-regulation: A social cognitive perspective. In M. Boekaerts, P. R. Pintrich, \&M. Zeidner (Eds.), Handbook of self-regulation: Theory, research, and applications (pp. 13 29). San Diego, CA: Academic Press

Zhou, L. (2007). Investigation and Analysis of English Learning Strategies on the Minority Students of Junior. Journal of Chuxiong Normal University, 22(4), 93-99.

Yang, M. N. (2007). Language learning strategies for junior college students in Taiwan: Investigating Ethnicity and proficiency. Asian EFL Journal, 9(2), 35-57. 